\title{
Translating linguistic time
}

\author{
Tal Goldfajn \\ Tel Aviv University
}

If Sartre is right and the tense of a text holds the key to its special strangeness (1947), how does this strangeness fare in translation? What can we learn from looking at the translation of grammatical tense and aspect in narrative texts in different languages? It is often simply assumed that translating grammatical categories of time in languages - because it has to do with what is considered the hard core of language, i.e. the grammar as opposed to the lexicon of the language - mainly involves mere linguistic constraints. Jakobson's famous motto (1987: 433) - "languages differ essentially in what they must convey and not in what they can convey"-would therefore suffice to tell the whole story about the way in which linguistic time is translated. This paper argues, however, that this is not the whole story: it argues that the choice of tense in translation is more than just a grammatical agenda, and may actually reflect a number of different commitments. Section 2 examines some intriguing tense changes in the translation of children's literature: it discusses the motivations behind these changes and shows that by changing the 'how' of the original story through the tense choice the entire subjective perspective of the text is altered. Section 3 identifies a few patterns in the translation of past distinctions in Modern Hebrew. It suggests that in contrast to the more diversified means of translating aspectual meanings in previous decades, a major trend in the last decade or so has been to reduce all past sphere distinctions essentially to one single form, i.e. the simple past tense. Finally section 4 deals with the classical problem regarding the Biblical Hebrew tenses and their translation; it shows that the translation of the biblical verbs may be strongly determined by the different linguistic ideas (and even systematic theories) the translators adopt regarding the Biblical Hebrew tenses. In all these cases then, we observe that the translation of temporal meanings involves not only a commitment to specific temporal interpretations but also a commitment to more subtle conceptions of subjectivity in translation, of literary conventions and linguistic ideas.

\section{Translation and Lesbia's sparrow}

In his Introduction to a new anthology of love stories entitled $M y$ Mistress's Sparrow is Dead (2008), J. Eugenides refers to the Latin poet Catullus, who wrote poems about his desire for his girlfriend Lesbia and the pet sparrow that keeps getting in the way. Lesbia adores the sparrow, 'whom she plays with, whom she cuddles' and has no eyes for the poet. 
And then the sparrow dies. But when the sparrow dies, Lesbia is too melancholic to pay any attention to the poet. Thus things were bad with the sparrow around, remarks Eugenides, things are bad with the sparrow gone. Love stories (but not necessarily love), he goes on to argue, depend on disappointment, on unequal births, on dysfunctional families and matrimonial boredom. Love stories do seem to give love a bad name. For despite the diversity of subjects, languages and cultures, the conclusion regarding love stories is that "one Catullan requirement remains in force throughout ...either there is a sparrow or the sparrow is dead" (Eugenides 2008: xi).

This Catullan requirement is often present when translations in general, and literary translations in particular, are examined and judged. "When I read literature in translation", writes one reviewer epitomizing a typical comment on translation, "it can take a long time to become attuned to the author's voice, which can have a sort of generic 'literature-intranslation' tone. Even with very good translations, there are times when you can hear the cogs turning, or feel that the work remains resistant to translation". ${ }^{1}$ According to this common view, then, there would always be some hampering sparrow getting in the way when translating from one language to another. What is worse, many translations would paradoxically point to what is 'resistant to translation'. In other words, the products of the process of translation are said to reveal the 'impossibilities of translation' hence, the translation dead sparrows.

This paper deals with a number of intriguing issues that arise when we examine the translation of temporal meanings in a few languages, and tries to say something beyond Catullus's sparrow equation. Temporality is one of the key sub-systems of language. Moreover, since languages map time in different ways, and there is clearly no one to one correspondence between tenses and aspects among different languages, this has inevitably important implications as far as translation is concerned. In analyzing this specific topic, as in many other topics related to literary translation, we could spend much effort on pointing to the hampering 'pet sparrow', namely focusing on the difficulties and impediments that appear when translating temporal meanings between different languages. Hence, within this approach, one typical question would be: how can we satisfactorily translate from languages with clear aspectual distinctions (progressive vs. non-progressive forms, for instance) such as English and the Romance languages into a language like Modern Hebrew which is not marked for aspect? Alternatively, we can choose to cry over the dead sparrow, showing how the translation of temporal meanings involves such intractable problems that justify the invocation of 'untranslatability'. One would ask here, dead-sparrowingly, something like: how can we possibly translate the innovative, salient, and subjectivity-laden use of the passé composé (instead of the expected passé simple) in Camus's L'étranger into languages where the passé composé-passé simple distinction is non-existent? 
My guiding question throughout this paper is: what can we learn from looking at the translation of grammatical tense and aspect in narrative texts in different languages? ${ }^{2}$ Narrative studies as well as linguistic research have shown that tense and aspect perform a variety of functions both in narrative and non-narrative texts. Thus in narrative texts in particular, tense and aspect fulfil such textual functions as progression, sequentiality, duration, the expression of foreground and background information, and the marking of subjectivity (See Fludernik 2003, Smith 2003). And yet, surprisingly, hardly anything has been written on the subject of translating the narrative functions of temporal markers.

Moreover, my main concern is not with what is lost in translation, for, surely, if we translate from a language with multiple grammatical means to express the past such as French or Spanish into a language with fewer grammatical means like Modern Hebrew we are bound to lose something. I am rather more interested in what we can find in translation. I am concerned, first, with identifying a number of operations and strategies we find in some translations of temporal markers, as well as with tracing their consequences. Secondly, I focus on a more theoretical question: what do these operations and strategies reveal about translation in general, for instance, about its various functions or the different linguistic ideas that inform it? Are these translations mere oddities or do they tell us something more specific about the translation of narrative?

In 'Time, Tense and Aspect in Kafka's "The Burrow", the South African literary critic and Nobel Prize writer J.M. Coetzee (1981) explores the relations between the verbal system of German and the narrative structure in this specific story by Kafka. While trying to explain the puzzling and often labyrinthine tense sequences of the original German in order to establish the story's extraordinary time structure, Coetzee refers to the English translation by the Muirs (1981:562):

The Muirs try to follow its [the tense sequence's] twistings and turnings, but there are unavoidable moments when they have to choose between progressive and nonprogressive forms (die ich hier beobachte becomes "which I am looking at here" rather than "which I look at here") and between perfect and preterite (bin fortgelaufen becomes "fled" rather than "have fled"). There is no way, in fact, of translating the passage without committing oneself from moment to moment to an interpretation of its time-structure, in particular of the situation in time of the moment at which the narrator speaks:... (the emphasis is mine)

The keyword here, for us, is 'commitment'. When translators choose one temporal option among other options available in the target text, they are committing themselves to a specific interpretation of the text's temporal structure. But I want to use this term in order to argue that the choice of 
tense and aspect involves far more than a commitment to specific temporal interpretations. The translator's choices are interesting because they reveal something about his/her commitment to broader interpretations regarding the subjective perspective of the text (see section 2 below) as well as about his/her conceptions of translation, literary conventions and linguistic ideas (sections2, 3 and 4). It is precisely on these commitments that I will concentrate in the following sections.

\section{The present tense in Hebrew translations: Rosie the hen, Shiloh the dog and the Israeli army's language}

The present tense, according to Fludernik 2003, has three main uses in narrative texts:

- The use of the present tense to refer to the narrator's and/or reader's here and now - it is therefore a deictic use of the present tense

- $\quad$ The intermittent use of the present tense in a past tense context

- The consistent use of the present tense in the entire text or in long passages of the text

The first narrative use, i.e. the deictic use of the present tense, includes such things as the narrator's authorial comments, gnomic and proverbial statements, and addresses to the narratee. The second use is the one traditionally known as the historical present tense and involves the shifting, in one or a few sentences, into the present tense whereas the rest of the narrative is in the past tense. The historical present commonly serves to highlight climactic points in the text, and is therefore often associated with extra vividness and dramaticity. The third use - generally known nowadays as the epic present, fictional present or narrative present - is the one we find in various present tense texts that abound these days: the present is the standard narrative tense and thus cannot be simply explained in terms of the historical present. This narrative present has, moreover, many different functions which are mostly connected to the fact that the present tense in languages is normally aspectually imperfective (it depicts only part of a situation, leaving it open and viewing the situation as unbounded). ${ }^{3}$ Very often present tense narratives are taken to foreground the time of the narrated experience and to produce a more fictional effect (Fludernik 2003). In this section, I will be mainly concerned with the translation of the historical present and the narrative present.

Writing about the implications of changing the tense in the translation of children's picture books into English, Lathey (2006) quotes Bell (1986, reproduced in Lathey 2006), one of Britain's most important translators of children's literature, who says the following concerning the use of the historical present in English: 
I am most reluctant to use the historic present in English in a middleof-the-road kind of children's novel, even if it is the main tense of a French or German original. In English, the historic present seems more a tense for a stylist than is necessarily the case in other languages. I like it myself; I like its immediacy. But I feel it needs to be approached with caution in translating children's fiction.

Bell's opinion on the historical present tense (which also seems to conflate in it the narrative present tense mentioned earlier) has broader implications. It suggests first of all, as Lathey rightly points out (2006:134), that tense in narratives may be linked to dominant literary conventions within languages. I would add, however, that it very often has to do with what translators and editors believe and maintain is the acceptable literary convention, without it necessarily being entirely the case. ${ }^{4}$ Likewise in a few Modern Hebrew translations, where the main tense has been changed from the original narrative present tense to the past tense, the same argument is invoked; namely, the idea that, in Hebrew, this use of the present tense does not work very well, or alternatively that there is no literary convention in Modern Hebrew that would allow these present tense narratives. And yet, such present tense narratives as Robbe-Grillet's La Jalousie (1957), Coetzee's Waiting for the Barbarians (1980), McCourt's Angela's Ashes (1996), Hoffman's Lost in Translation (1989), Ondaatje's The English Patient (1992) or many of Carver's stories, to give just a few examples, have all been translated into the Hebrew present tense and seem to 'work' rather well. We shall return to this soon.

Most significantly, Bell's comment above suggests furthermore that such a hard core grammatical category as tense can be used as a means to assimilate a source text into the target culture. Lathey examines in her article a striking example of one such alteration of tense: i.e. the British edition of Jean de Brunhoff's classic picture book Histoire de Babar (1931) in which the translator changed the main narrative tense of the original French from present tense to past tense in English. ${ }^{5}$ Lathey analyses the causes and effects of the tense shift in Babar's British edition in order to identify the properties of the historical present that are lost in the translation of this picture book. Thus, if in the original French Babar the present tense has the crucial function of 'calling forth' past events into the present, the English change of tense has the clear effect of relinquishing the present tense's visual qualities as well as its immediacy. The change in the basic narrative tense is, furthermore, bound to bring about a change in the narrative triangle in a read aloud event - certainly a central characteristic of children's books - because "the intimacy of the relationship between the narrative voice of the adult reading aloud, the child who listens and imagines, and the images quickened by both adult and child, are enhanced in the case of the French original by the present tense" (Lathey 2006:139). This last point, inasmuch as it refers to the special narrative intimacy triggered by the read aloud element involved in children's literature, 
stresses some of the specific problems posed by the translation of a picture book:

Surely the narrative intimacy of the present tense, which potentially affords the closest possible relationship between narrator and addressee, is one of these qualities that a translator should preserve, particularly when pictures contribute a third dimension to the read aloud performance. In the great forest a little elephant is born; or: 'In the Great Forest a little elephant was born' (de Brunhoff, 1989:3) - the present tense lends a tone and an aura to a narrative that $d o$ matter.

(Lathey 2006: 139)

The Brazilian Portuguese translation of Histoire de Babar (2002) likewise brings the translation of the first sentence in the past tense: "Na grande floresta nasceu um pequeno elefante" ("in the great forest a small elephant was born') and goes on to tell the rest of the story mainly in the present tense. It is as if the opening with a present tense was considered too odd or confusing for the child. To open with a past tense, on the other hand, is to commit oneself to a more orderly, sequential time interpretation of events. It brings the text closer to the commonsensical view of the traditional past tense narrative, according to which first things come first, they do so in the past tense, and consequently render the sequence of events on the time line simpler and more explicit.

The choice of the present tense in narrative, then, surely matters. And yet, as the example from Portuguese above illustrates, it is not only where the translation into English of children's books are concerned that we find a cautious response to the translation of the present tense. In effect, a few Modern Hebrew translations of children's books likewise disclose the same phenomenon. In 2003, Phyllis Raynolds Naylor's prize winning novel for young readers, Shiloh (1991), was translated from English into Hebrew. Shiloh tells the story of a young boy's compassion for an abused dog and his decision to help the dog. The novel is written throughout in a specific representation of West-Virginian sociolect and in the narrative present tense. This is how it opens:

The day Shiloh come, we're having us a big Sunday dinner. Dara Lynn's dipping bread in her glass of cold tea, the way she likes, and Becky pushes her beans up over the edge of her plate in her rush to get 'em down. (Naylor 1991: 1)

The Hebrew translator chose to switch the narrative tense of the novel from the present (and the present progressive) mainly to the past tense in Hebrew, raising the obvious question concerning the underlying motivation for such a major change: did the translator think that the literary conventions prevalent in Modern Hebrew children's literature exclude in fact such narrative use of the present tense? Or did he rather assume that the 
Hebrew present tense in general could not be used with such a narrative function independently of the genre? We actually get an insight into the motivations of his specific temporal choice from his reply in the press to one of the reviewers of the book. Regarding the change of tenses, the reviewer had asked whether the Hebrew translator or editor had not been aware of the singularity and importance of the present tense use in the original English. Such a translational choice, the reviewer rightly points out, ignores the fact that "not only the story is important [in a book such as this] but also the way the story is being told" (Padan 2003). The title of the translator's reply - namely, "translationese present tense" - already hints at the fact that, in his view, the use of the present tense in such a narrative context would be artificial, alien to the Hebrew language and its literary conventions, hence, some sort of translationese tense. He declares furthermore in his letter that although he was definitely aware of the textual implications of the tense choice, he nevertheless discarded the choice of the present tense: "not only because of the inarticulate effect it would have [on the language/translation], but - alas - because it reminds one of the ugly language of the Israeli army investigations which swarms nowadays in the media" (Katz 2003). This is not the place to discuss the language of the Israeli army, yet it is important to note nonetheless that the association of the army language and the present tense is based, in my opinion, not on some peculiar use of the present tense as part of a specific 'jargon' or sociolect (as the translator's reply might suggest). Rather, I think that the present tense in this context functions as a mark of a more general current report genre - an oral genre which includes sport reports and eyewitness news coverage for instance - where the present tense is used to verbalize an event which is being told as if simultaneous with it being seen.

For although both past and present tenses can be used to refer to past events, the two are clearly not equivalent. As Fleischman has convincingly shown in her study on tense and narrativity (1990), the choice of the present tense in narrative always involves some special information. Fleischman examines the special qualities of the present tense from Medieval performance to modern fiction, and argues that the use of the present tense provides particular textual and expressive effects precisely because, for instance, it allows a certain play between the reading 'simultaneity with now' offered by the tense itself and the exclusion of this reading in the rest of the past narrative text. It is this play that triggers the common perception that the events are taking place before the speaker's eyes. In this narrative use of the present tense, the latter shares with the past tense such properties as: past time reference, reference to unique situations, foregrounding, and also sequentiality as a contextual implicature. The present tense, on the other hand, differs from the past tense - and this is crucial - in its expressive component. This expressive component involves the linguistic devices relating to the social, affective and conative functions of language, and includes the speaker's/narrator's personal attitudes towards what he/she is saying. Thus the expressive properties brought about by the use of the 
present tense are, for instance, 'lack of distance' - hence immediacy - and 'lack of objectivity' - hence subjectivity. These are features that appear in activities where seeing and speaking are synchronized, as in sport reports or eyewitness news coverage mentioned earlier. While in narration the rule is commonly 'live first, tell later', in current report genres speakers verbalize, using the present tense, what they see as they see it. Present tense narrative, remarks Fludernik (1996: 252), "attempts to square the circle, performing the blatantly impossible: it narrates 'as if' in the preterite, but does so in the present tense. The effect of such present-tense narrative, however, is of surprising inconspicuousness; one hardly notices at all that the text employs the present tense". Yet, the different subjective meanings and perspectives triggered by the different tenses are nonetheless noticed by the reader.

The stylistic effects obtained, then, from the narrator's choice to use the present tense in Shiloh - such as the 'eyewitness', the 'visualizing' and the 'immediacy' effects (which, very significantly, are all effects that the past tense cannot offer) - are, indeed, similar to the effects we get from using the present tense in current report genres in Hebrew (and not only in Hebrew of course). But what could have been grasped as a reasoning for positively using the present tense in the translation, is actually inverted and taken to be the reasoning against making such a choice, on the grounds that it fosters an unwelcome association. The association here, as we have seen, is not simply with the army language, but rather more broadly with a marked oral, spoken-oriented genre in general.

Shiloh Season was published in 1996 as a continuation to the first Shiloh, and translated into Hebrew ten years later by two other translators who, nonetheless, stuck to the decision to switch the main narrative tense from the original English present tense to the past tense in Hebrew. Apparently, this time round the justification for the reiterated choice was the idea that changing the main tense of the text would not affect the text itself; in other words, that there is no real significance to the original choice of the author to tell the story in the present. According to one of the translators (Padan, personal communication), the use of the present tense as the main narrative tense in adults' literature might often be meaningful, whereas in children's literature it is of secondary importance. ${ }^{6}$ Consequently, the original on-the-scene narration of Naylor's English text is erased in this Hebrew translation. The effect is a more distanced and less subjective narration in the target text. By changing the 'how' of the original story, the subjective dimension of the text is significantly altered, proving yet again that the choice of a tense is far from being a mere grammatical idiosyncrasy.

The Hebrew translation (2006) of the classic picture book Rosie's Walk (1968) by P. Hutchins presents a rather different example. While there is a switch of tense in the translation here too, the switch is in the opposite direction. The original English text is written in the past tense: "Rosie the hen went for a walk/across the yard/around the pond/over the haystack/past the mill/through the fence/under the beehives/and got back in time for 
dinner." Neither Rosie nor the text ever notice the fox that tries to catch her, but we, the readers, know that from the pictures. Unwittingly, she foils the fox at every turn, and in the end he is driven off by a swarm of bees. Rosie returns undisturbed and unperturbed to her roost in the hen house. Just like in my summary here of the story, the Hebrew translator decided to turn the whole past mini narrative into the present tense so: "Rosie the hen goes for a walk/ across the yard/around the pond....etc.... and gets back in time for dinner." By employing the present tense, the translator moves away from the narrative prototype (and this is clearly not narration in the historical present for there is no past time reference). The use of the present tense here serves to foreground the visual and privilege description over events. Moreover, the descriptive capacity of the present tense (an implicature of its imperfective aspect) and its feature of 'simultaneity with now' provide a more immediate and subjective perspective. Consequently a different discourse is constructed, one that opts for recording what is happening at the moment, one which has a very different subjective position from the one found in the source text.

It is often simply assumed that translating grammatical categories of time in languages - because it has to do with what is considered the hard core of language, namely the grammar as opposed to the lexicon of the language - involves mere linguistic considerations or constraints. Thus in this view, tenses and aspects are translated according to the specific temporal distinctions grammaticalized in the target language or else are conveyed lexically. Jakobson's famous motto (1987: 433) which says that "languages differ essentially in what they must convey and not in what they can convey" would therefore suffice to tell the whole story about the way in which linguistic time is translated. Indeed, the translation of tense and aspect meanings is surely subject to the particular temporal grammatical structure of languages. And yet, I have been arguing that this is not the whole story: the translation of linguistic time is not predetermined by strict linguistic constraints of the languages involved. What the examples in this section suggest is that other factors are also at play. The choice of tense may be motivated, as we have seen above, by certain translators' beliefs regarding the use and meanings of the tenses in the target language; the idea, for instance, that the present tense in Hebrew has certain possible functions but not others (like the narrative uses), or that in English in general it is more marked than in French. Or beliefs regarding the linguistic and literary conventions prevalent within a specific discourse medium, genre or register; the idea maintained by some translators, for instance, that the narrative present tense belongs to a more oral medium, to current report genres or, in the case of Hebrew, to the army language but not to children's literature.

I would like to stress, furthermore, that these tense shifts in translation emphasize the crucial relation between tense choice and subjectivity. I use here 'subjectivity' with reference to two distinct levels. The first level refers to the subjective dimension of the text itself; the fact 
that, by choosing specific tenses, translators very often commit themselves not just to specific temporal interpretations of the text - i.e. to particular temporal mappings of the text - but also to specific subjective perspectives within the texts. All the examples discussed in this section - from picture books to young readers' texts - show that changing the dominant tense in the translated text affects the 'how' of the original story, and by doing so the subjective dimension of the text is altered significantly. Many of the categories I used in this section when analysing the various textual effects of the different tense choices - namely, eyewitness and visual effects, deicticity, immediacy, objectivity, distance, involvement, dramaticity, vividness and experentiality among others - entail some kind of subjective position. They all constitute and define the subjective perspective of the text as a whole, the subjective position of the narrator as well as that of the reader.

The second level refers to the translator's own subjective/ethical position that appears in his/her tense choices. As it appears from the translators' motivations above as well as from the effects of their decisions, the choice of tense may be used as a means to assimilate texts to the target culture. In most of the examples discussed in this section, the translators shifted the main tense of the narrative in order to adapt the source text to what they assume is a more standard and acceptable use of the tenses in the target language. I should add, nevertheless, that the translation of tenses by itself does not have to be necessarily an assimilationist manoeuvre. As we will see in the following section, the choice of tense and aspect can similarly serve as a means of positing a more resistant and creative stance in translation.

\section{The reductionist approach: translating aspectual distinctions into Modern Hebrew}

What happens when aspectual distinctions, in particular the perfective/imperfective distinction defined below, which have important textual functions in languages such as English, French and Spanish, among others, have to be translated into a language such as Modern Hebrew where there is no grammatical aspect? Let us first look quickly at the category of aspect and its relation to foregrounding and backgrounding in texts.

Tense and aspect are commonly thought of as complementary systems and in most languages they are in fact intertwined: we say that while tense locates situations on the time line, aspect has to do with the internal temporal structure of a situation expressed by a sentence. Aspect then conveys a temporal viewpoint which focuses all or part of a situation, "like the lens of a camera" in Smith's words (2003:68). Moreover, it is standard to distinguish (see Comrie 1976; Smith 1991 among others) between two main viewpoints, namely the perfective and the imperfective. The perfective aspect presents the situation as a single whole and closed, 
and therefore determines a situation as bounded. The imperfective aspect, on the other hand, presents only part of a situation, leaving it open (i.e. without information about its endpoints), and therefore determining the situation as unbounded. In English, these two main viewpoints are marked morphologically: i.e. the perfective by the simple verb form; the imperfective by the verbal auxiliary be + ing. In Romance languages such as French, Spanish and Portuguese, the perfective/imperfective distinction appears very clearly within the past sphere, for instance, where we find a perfective pretérito simple or passé simple as opposed to an imperfective pretérito imperfecto or imparfait (in Spanish and Portuguese we find in addition the progressive estar + participle). In Modern Hebrew, on the other hand, the category of aspect is not marked on the verb, and there is just a periphrastic construction (the past tense of 'to be' + the participle 'beinoni') which serves to convey past habitual situations (as well as unreal conditions). ${ }^{7}$

The foreground/background distinction is based on the idea that the foreground of a narrative (see Hopper 1979, Smith 2003: 35) consists of situations that advance the narrative, whereas the background consists of information which does exactly the opposite, i.e. fails to contribute to the progression of the narrative. Moreover, it is common to think of the foreground as having to do with the main sequential events of a narrative, and the background as providing the descriptive and supportive information. Aspect is involved in this foreground/background distinction inasmuch as foreground situations are normally bounded events conveyed by the perfective viewpoint which follow each other in a sequence. In contrast, background situations are typically conveyed by the imperfective viewpoint. So, rephrasing my initial question, what happens when we have to translate from these languages where aspectual distinctions as the perfective/imperfective perform specific textual functions, like foregrounding and backgrounding information in narrative, into a language such as Modern Hebrew where there is no grammatical aspect? Do the source text aspectual meanings disappear altogether in the target text for instance? Or, if not, what are some of the textual translation means employed, besides, of course, the resort to lexical means, in order to convey these specific aspectual distinctions? And, finally, what do these translation means tell us about the translators' conceptions of translation and language?

If we take three different Hebrew translations of Lewis Carroll's Alice's Adventures in Wonderland (1970) - Siman's translation from 1927, Amir's translation from 1951 and Litvin's translation from 1997 - and look at the various strategies these translations employ in order to convey the original's temporal mapping, we can observe some interesting differences in their specific approaches to the marking of aspect within the past sphere. The following short passage from Chapter 5 (where Alice eats from the mushroom the Caterpillar gives her and grows very tall) illustrates in a nutshell the different strategies used by the different translators: 
(1) She had just succeeded in curving it down into a graceful zigzag, and was going to dive in among the leaves, which she found to be nothing but the tops of the trees under which she had been wandering, when a sharp hiss made her draw back in a hurry: a large pigeon had flown into her face, and was beating her violently with its wings. (Carroll 1970:7475)

If we concentrate on the linguistic means whereby the imperfective aspect ('had been wandering', 'was beating') is expressed in either of the two Hebrew translations of the passage above, we find that in Siman's translation from 1927 the iterative aspect (as expressed by the English 'was beating') is expressed by the reduplicated construction of two Hebrew past tenses (the qatal form) in sequence where one of them is the verb 'to come' which serves here to convey iteration - lit. 'the bird flew and came' (note that this Hebrew translation employs compensation inasmuch as it marks aspect not necessarily where it appears in the English text, i.e. 'was beating'; this sentence in the original for instance is actually in the pluperfect - 'had flown'). Moreover, the continuous unbounded action 'was beating' is rendered by the Hebrew past tense using a specific verb morphology conjugation - the piel ('niqer') - which interestingly enough also produces the effect of imperfective iteration. Therefore, in this particular translation the two means chosen to express imperfectivity (even if only iterativity) are reduplication of the past tense verb and the resort to the Hebrew's rich root-based verb morphology.

In Amir's translation of 1951, we similarly find the verb's morphology - this time the hithpael conjugation ('hit'ofefa') - being used to convey iterative aspect. But, more significantly, we also find the periphrastic construction 'to be' in the past + participle serving to translate the imperfective aspect ('hayta mithalekhet'). Furthermore what is interesting about Amir's use of this construction is that he applies the latter not only to convey habitual events or iterative ('hayta hovateta') in the past, which is the standard usage, but actually overextends its use to convey likewise duration. Thus a form normally associated with the specific imperfective meaning of iteration appears here to cover also the imperfective meaning of duration. I should add that this overextension is very polemical and considered substandard.

In contrast to the two previous translations, R. Litvin's 1997 translation brings the whole passage quoted above in the past tense, seven in all, one of them in the hithpael conjugation as in our previous translation. Therefore, we find that the four different temporal constructions marking both tense and aspect in the original English are reduced in this modern translation to one single verbal form, i.e. the past tense - which is supposed to cover them all. It does work, but there is no mark of aspect in the text. ${ }^{8}$ 
So while the earliest translation relies heavily on morphological (the use of the special verb conjugations) and syntactic means in order to convey aspectual nuances, the second one not only employs the morphological recourse but also overextends a construction (haya + participle) used standardly for habitual meaning ('she used to eat apples every day': 'hi' hayta 'okhelet tapuhim kol boker') so as to cover (non-standardly) the continuous/progressive/durational aspectual meaning as well ('she was walking when I saw her': 'hi' hayta holekhet k'asher ra'ity 'ota'). But the most striking difference is the one between the first two and the one from the 1990's. In fact, my argument here is that it points towards a major trend in the translation of past time narratives in Modern Hebrew. In contrast to the more diversified means of translating aspect in previous decades, a dominant pattern in the last decade or so has been to reduce all past distinctions to one single form, the simple past tense. Morphology might still be resorted to, but the periphrastic means and even more dramatically the use of the beinoni (as an adjunct gerund) in the past sphere are mostly excluded. If we compare, to give one example among many, the two different Hebrew translations of Hemingway's The Old Man and the Sea (1953), we observe one major difference in the use of the tenses. While the 1994 translation gives us the beinoni being used in the past sphere (as a gerundive or complement to a perception verb for instance), the most recent translation of 2005 rewrites these passages with the simple past. The oftenheard argument is that the beinoni participle should be avoided in past time contexts, that it should be restricted to its use as the present tense, that when in past time spheres it is not proper Hebrew, it is translationese. And yet, the history of this particular form as well as various Hebrew source texts do not seem to support this argument. It is as if the prevalent temporal principle being applied is one that says that the three tenses in Modern Hebrew refer strictly to the present, past and future times, thus ignoring entirely the fact that tenses and aspects have more than one use and in fact perform a variety of textual functions.

This minimalist or reductionist approach which relies entirely on the past tense appears, indeed, in many Modern Hebrew translations of Portuguese and Spanish texts with a rich perfective-imperfective interplay in the past. Consider this short passage from Clarice Lispector's (1960: 130) short story $O$ Búfalo:

(2) Levantou-se do banco estonteada come se estivesse se sacudindo de um atropelamento. Embora ninguém prestasse atenção, alisou de novo a saia, fazia o possível para que não percebessem que estava fraca e difamada, protegia com altivez os ossos quebrados. Mas o céu lhe rodava no estômago vazio; a terra que subia e descia a seus olhos, ficava por momentos distante, a terra que é sempre tão difícil. Por um momento a mulher quis, num cansaço de choro mudo, estender a mão para a terra difícil: sua mão $\underline{\mathrm{se}}$ 
estendeu como a de um aleijado pedindo. (Lispector 1960: 130)

[She stood up from the bench, dizzy, as if she was shaking herself off from a trampling. Although nobody was paying attention to her, she straightened her skirt again, she was doing everything she could so that nobody would notice she was weak and slandered, she was protecting proudly her broken bones. But the sky was turning in her empty stomach, the earth which was going up and down before her eyes, was distant at times, the earth which is always so difficult. For a minute, the woman wanted, out of a tiredness of silent cry, to stretch her arm to the difficult earth: her arm stretched out like a begging crippled.]

The past perfective verbs appear at the beginning and at the end, framing a whole sequence of imperfectives in the middle. Whereas the perfectives move the reference time forward, the imperfectives serve as background. The translation of this passage into Hebrew (1999) goes for the minimalist option, and renders all forms in the simple past. The result is a more staccato sequential narrative text, which ends up relying on the stative lexical meaning of specific verbs in order to break sequentiality.

A particularly instructive example is the translation into Hebrew (2005) of Cortázar's story Continuidad de los parques (1994), one of the most anthologized stories in college textbooks. In a little more than five hundred words, Cortázar tells the story of a man sitting in a green velvet armchair and reading about an adulterous couple that is planning to murder the woman's husband. The story ends with the woman's lover coming out of the novel and creeping behind the green velvet armchair where the husband/reader is reading. The story clearly plays with the boundary between fiction and non-fiction, and ingeniously uses the aspectual contrast preterite/imperfect in Spanish to demarcate the boundary. Thus while the first nineteen lines of the story are constructed with the standard use of the preterite for foregrounding past events and the imperfect for background, from the twentieth line down to the thirty-fourth there is a tense alteration and the dominant verb form used is then the imperfect, with a few pluperfects, but no preterites. The man in the story is absorbed by the novel he is reading: "Primero entraba la mujer, recelosa; ahora llegaba el amante, lastimada la cara por el chicotazo de una rama. Admirablemente restañaba ella la sangre con sus besos, pero él rechazaba las caricias ...el puñal se entibiaba contra su pecho..." and so on [The woman arrived/arrives first, apprehensive; now the lover came in/comes in, his face cut by the backlash of a branch. Admirably, she stanched/stanches the blood with her kisses, but he rebuffed/rebuffs her caresses...The dagger warmed/warms itself against his chest...] This aspectual play then triggers the interpretation that the whole passage is a fictional one; these are the fictional events the reader 
is reading about which are distinct from the non-fictional events in the rest of the story conveyed mainly by the preterites.

The translation into Hebrew, in its turn, brings the whole story in the past tense, thus no contrast, no fictional-nonfictional opposition. The beinoni participle which could have been employed here and would have done the job (the equivalent English would be something like 'first the woman goes in... now the lover arrives ...etc') is totally absent, the consequence is that the narrative structure of the original text, constructed so interestingly upon the aspectual structure, becomes something else in the target text.

There are a few translations that do nevertheless employ the beinoni participle in the past sphere; the latter are very instructive given their exceptional place within the major reductionist trend. One such example is the translation (2000) of Raymond Carver's short story Gazebo (1993: 18). This short story begins like this:

(3) That morning she pours Teacher's over my belly and licks it off. That afternoon she tries to jump out the window.

I go, "Holly, this can't continue. This has got to stop."

We are sitting on the sofa in one of the upstairs suites. There were any number of vacancies to choose from. But we needed a suite, a place to move around in and be able to talk. So we'd locked up the motel office that morning and gone upstairs to a suite.

She goes, "Duane, this is killing me."

We are drinking Teacher's with ice and water. We'd slept awhile between morning and afternoon. Then she was out of bed and threatening to climb out the window in her undergarments. I had to get her in a hold. We were only two floors up. But even so. (Carver 1993: 18)

The story opens with the narrative present tense we dealt with in the previous section; it emphasizes the time of the narrated experience. Three imperfective progressive constructions appear in this opening section. The two present progressives 'we are sitting' and 'we are drinking' appear each at the beginning of a paragraph in a nicely symmetrical way. Both sentences come after a direct quotation sentence (having a deictic use of the present) and mark a beginning of some sort; both sentences are followed by a sequence of sentences in the past including simple pasts, pluperfects and one past progressive. We might say that these two present progressive sentences expressing duration in fact zoom in into a certain picture of the situation and serve to describe a background situation which will, in the following sentences, be developed and specified further. They do not move the time forward in the narrative and therefore fit into the background definition of imperfectives. The third progressive - "then she was out of bed and threatening" - is however different: it is preceded by the pluperfect 
situation 'we had slept awhile' followed by the conjunction 'then' and a stative sentence. Now this imperfective construction, the 'threatening' one, at this specific point in the text seems to be a marker of a significant change. It shifts from whatever came before in the text into the progressive form in order to highlight a major juncture of the story, we may therefore consider it as having a foregrounding effect.

What happens in the Hebrew is that, not having a marked form to indicate duration, all the English present tenses, as well as the two present progressives of the background, get translated by the same Hebrew participle beinoni acting as the present tense. The Hebrew translation, then, is clearly a more homogeneous and monolithic text once the original temporal shifts, i.e. the present-present progressive interplay, and the consequent hierarchical texture produced have been flattened (the pluperfect distinction also disappears in the Hebrew since there is no such grammatical option and no lexical compensation was employed). But this is not the whole answer to our initial question. When it comes to the third imperfective form, i.e. 'she was out of bed and threatening', which as we saw is deployed for foregrounding, the translator did not choose what would be the more standard option nowadays of the simple past once there is no marking for past duration in Hebrew, but actually resorted to that same participle used before, except that this time since it appears in the marked sphere of the past instead of the present, it acts as a gerund and does succeed in conveying both aspectual duration as well as foregrounding. So what is interesting is that the same form, i.e. the participle, which in the present sphere was of no help to indicate the background because there was no tense /aspect alternation possible, was actually able to mark the foreground due to the specific narrative context. This example shows, I believe, that the choice of tense translation, even within a limited scope of choice as we have here, can be deployed creatively to reproduce some of the textual distinctions of the source temporality as well as to stretch the limits of the language and of translation.

\section{4. "Better a sparrow, living or dead, than no birdsong at all"}

This final section examines briefly how various translations of the Hebrew Bible have dealt with the notorious problems related to the tenses in Biblical Hebrew. Here again we observe that the choice of tense in translation is more than just a grammatical agenda, as it reflects a number of different commitments. Like in the areas presented in sections 2 and 3, the translation of the biblical tenses involves far more than a commitment to specific temporal interpretations. In effect, I suggest that the translation of the biblical verbs may be strongly influenced by the different linguistic ideas (and even systematic theories) the translators adopt, implicitly or explicitly, regarding the Biblical Hebrew tenses. In his article on "The Participle of the Immediate Future and Other Matters Pertaining to Correct 
Translation of the Old Testament", W. F. Stinespring contends that the specific use of the active participle in Biblical Hebrew (the beinoni again) in order to express the immediate future "is recognized by the grammarians but often neglected by the translators" (1970:64), implying that grammarians and translators all too often take different and unconnected paths. I will argue exactly the opposite here, namely that there is a close connection between specific linguistic accounts and translation when it comes to the translation of the temporal component in Biblical Hebrew (henceforth BH). ${ }^{9}$ Since at least the tenth century, the four main BH verb forms - qatal, yiqtol, weqatal and wayyiqtol - have received many and very distinct temporal interpretations. The standard view since the nineteenth century has been that these forms signal perfective and imperfective aspect. I have argued elsewhere (Goldfajn 1998), however, that the primary function of these forms is not to mark aspect as it is commonly held but rather to locate events in relation to temporal coordinates in the text. In this last section, I want to suggest that depending on whether the translators adhere to a tense-based account of BH or to the aspect theory or to any other theory for that matter, their actual rendering of these forms will be different.

A good example is provided by the comparison of two modern French translations: La Bible du Rabbinat, originally translated in 1889 but revised in 1994, and Henri Meschonnic's twentieth century translation of various biblical books. If we look here at the Hebrew text in Exodus, chapter 3, vs. 1-10, and compare the two French renderings of this passage (Meschonnic 1999) we can identify a number of significant differences even within this short passage. First of all, the BH wayyiqtol form, the main temporal function of which is, in my opinion, to express temporal sequentiality/continuity and thus to advance narrative ${ }^{10}$ is rendered in the Rabbinat's version mainly by the passé simple but also by the plus-queparfait as in Ex 3:1:

(4) Or, Moise faisait (BH qatal form) paître les brebis de Jéthro son beau-père, prêtre de Madian. Il avait conduit (BH wayyiqtol form) le bétail au fond du désert, et était parvenu (BH wayyiqtol form) à la montagne divine, au mont Horev.

In Meschonnic's version we do not find the plus-que-parfait as an option for rendering the wayyiqtol. What we do find instead, however, is interestingly the dominant presence of the passé composé to translate many wayyiqtol sentences. In Ex 3:4, for example, the BH original contains 4 wayyiqtol forms (+1 qatal form) and reads as follows:

(5)

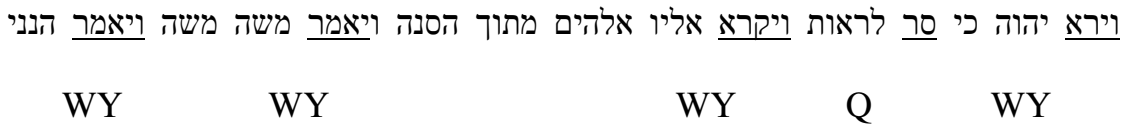


It is translated as follows in the Rabbinat's version:

L'Eternel vit qu'il s'approchait pour regarder, alors Dieu l'appela du sein du buisson, disant : "Moise! Moise!" Et il répondit: "Me voici".

[King James: 'And when the Lord saw that he turned aside to see, God called unto him out of the midst of the bush, and said, Moses, Moses. And he said, Here I am']

Note that the qatal form (the second verb form in the $\mathrm{BH}$ text) in the independent clause, a form which in this context serves to interrupt narrative and does not move the reference time forward, is rendered here by the French imparfait and is understood as being simultaneous with the previous event (the 'seeing'). The English translation by the Jewish Publication Society (1985) similarly understands the qatal form as interrupting narrative but unlike the above-cited French version it interprets this form in a dependent sentence as yielding not a simultaneous interpretation but an anteriority pluperfect interpretation: 'When the Lord saw that he had turned aside to look, God called to him out of the Bush'. Now, as for the wayyiqtol forms, the Rabbinat, as we can see, translates them (except for the 'saying' one) with the passé simple. In contrast, Meschonnic's translation of this verse is the following:

Et Adonai a vu qu'il a fait un détour pour voir

Et Dieu vers lui a appelé hors du buisson et il a dit

Moise Moise et il a dit c'est moi

All wayyiqtols as well as the one subordinate qatal form are rendered here by the passé composé. So what is the underlying principle behind this translation choice? Meschonnic himself in fact provides the answer in his Introduction to this passage's translation. He writes (1999:430):

Pour les temps, j'ai essayé de jouer de l'alternance entre les passés du discours et ceux du récit, pour rendre l'accompli hébreu. Mais en gardant toujours l'opposition des accomplis et des inaccomplis.

[As far as the tenses are concerned, I have tried to alternate between the past tenses of the discours and those of the récit, in order to convey the Hebrew perfective. But always keeping in mind the opposition between perfective and imperfective.]

From this explanation we learn that there are at least two main distinctions underlying Meschonnic's translation of the BH verbs. The first important distinction relates to the standard aspectual interpretation of the $\mathrm{BH}$ verbs according to which the main temporal distinction at work within the $\mathrm{BH}$ 
system is between perfective and imperfective aspect (and not tense). The second distinction has to do with Benveniste's (1966) founding distinction between discours and récit and his well-known idea that the French verbal forms do not actually make up one unified and monolithic system but rather constitute two temporal sub-systems, each one of them having its own group of dominant tenses. Thus the passé simple belongs to the récit/narrative temporal subsystem whereas the passé composé typically defines the 'discours' perspective. The relevant point for us is that these two distinctions in Meschonnic's interpretation of the $\mathrm{BH}$ forms have clear effects on his translation. It leads him to try to give them expression within his translation by choosing, for instance, the passé composé as the dominant past tense for discourse. But it also means that, as the example mentioned above suggests, the passé composé is similarly used when the perspective is a narrative one and not discursive, consequently overextending the use of the passé composé and thereby emphasizing a more discursive speech perspective in his translation.

Meschonnic's special attention to the Hebrew's temporal forms allows him, on the other hand, to recognize, for instance, that in verse 2 (KJ: 'And he looked, and, behold, the bush burned with fire, and the bush was not consumed') we have a specific temporal shift - namely, the wayyiqtol sequence is interrupted and after the adverbial 'hineh', often translated as 'behold', we have two beinoni participles - which indicates free indirect discourse and represents the character's content of perception as he is experiencing it:

$$
\begin{aligned}
& \text { וירא והנה הסנה בער באש והסנה איננו אכל } \\
& \text { Partc }
\end{aligned}
$$

Meschonnic translates these participles as present tenses, thus keeping himself very close to the actual $\mathrm{BH}$ forms as follows:

Et il vit et c'est le buisson il brûle dans le feu et le buisson n'est pas mangé

The Rabbinat translation renders it as follows:

Il remarqua que le buisson était en feu et cependant ne se consumait pas

Moreover, Meschonnic's closeness to the $\mathrm{BH}$ verb forms and his zealous attempt to translate each one of them by a different French tense so as to reflect in the target text the specific $\mathrm{BH}$ temporal mapping of the original appears likewise in the case of verse 3 where we have in the $\mathrm{BH}$ text a sequence of modal cohortatives + yiqtol: 
(7)

ויאמר משה אסרה-נא ואראה את המראה הגדל הזה מדוע לא יבער האש

The English JPS translation stresses the (deontic) modality of the original by the use of the modal operator 'must' followed by the present tense, ignoring (not incorrectly) that the $\mathrm{BH}$ forms are related to the so-called future form:

Moses said, "I must turn aside to look at this marvelous sight; why doesn't the bush burn up?"

In contrast, Meschonnic, informed by the idea that the modals and the future in $\mathrm{BH}$ are not only semantically but also morphologically related, maintains the whole sequence in the future tense and even distinguishes between the first cohortative and the two other yiqtol forms by translating them differently:

Et Moise a dit je vais faire un détour et je verrai cette grande chose à voir

Pourquoi le buisson ne brûlera pas

Compare the latter with the Rabbinat's rendering of the same verse:

Moise se dit: "Je veux m'approcher, je veux examiner ce grand phénomène: pourquoi le buisson ne se consume pas."

These are only a few examples, many more could be added. The point, however, is that when we examine some of the differences in the translation of the $\mathrm{BH}$ tenses we are able to recognize the influence that certain linguistic temporal accounts of the $\mathrm{BH}$ verbs have had on translation. This influence moreover should not be underestimated. It means, among other things, that we can actually account for many striking differences in biblical translations, rather than dismissing them as mere oddities. Consequently, as we have observed before in the case of children's literature and in Modern Hebrew translations of past sphere aspectual distinctions, the translation of the biblical tenses involves very often more than a commitment to specific temporal interpretations of the Hebrew text itself. Further commitments, such as the one related to underlying linguistic ideas about the Hebrew verb, may be importantly at play.

"Translation is the attempt to represent in one language a text produced in another language" is the definition that appears in the Conclusion of a comprehensive book on Bible translation (Wilt 2003:233). The use of 'attempt' says it all, or almost. "'Attempt' is used in recognition of the gap between goals and actual results", explains the author, "especially for Bible translators whose high regard for the source text 
encourages the goal of 'equivalence' at one level or another, in spite of the impossibility of fully achieving it...". 'The gap between goals and actual results', 'the search for equivalence', 'impossibility' - these living or dead sparrows will forever be more stimulating and inspiring (Catullus did not commit suicide, as we know, he kept on writing poems after Lesbia dismissed him) than no translation at all.

\section{Bibliography}

\section{Primary texts}

Carmi, Daniella (2003). A Journey on a Scooter (in Hebrew). Tel Aviv: Am Oved.

Carroll, Lewis (1970 [1865]). The Annotated Alice. Alice's Adventures in Wonderland and Through thr Looking Glass. Harmondsworth: Penguin.

Carroll, Lewis (1927). Alice's Adventures in Wonderland (tr. to Hebre by L. Siman). Tel Aviv: Omanut.

Carroll, Lewis (1951). Alice's Adventures in Wonderland (tr. to Hebrew by A. Amir). Tel Aviv: Machbarot Lesifrut.

Carroll, Lewis (1997). Alice's Adventures in Wonderland (tr. to Hebrew by R. Litvin). Tel Aviv: Hakibbutz Hameuchad.

Carver, Raymond (1993[1981]). What We Talk About When We Talk About Love. London: The Harvill Press.

Carver, Raymond (2000). What We Talk About When We Talk About Love (tr. to Hebrew by Moshe Ron). Tel Aviv: Am Oved.

Coetzee, J.M. (1980). Waiting for the Barbarians. Harmondsworth: Penguin.

Cortázar, Julio (1994). Cuentos completos. Madrid: Alfaguara.

Cortázar, Julio (2005). Final del juego (trans. into Hebrew by Yoram Melzer). Jerusalem: Carmel.

de Brunhoff, J. (1979[1931]). Histoire de Babar le petit elephant. Paris: Librairie Hachette.

de Brunhoff, J. (2002). A história de Babar o pequeno elefante (tr. By Heloisa Prieto). São Paulo: Companhia das Letrinhas.

Demiel, Yitzhak (1990). The Shabbat's Dress of Little Hannale (in Hebrew). Tel Aviv: Kineret.

Eugenides, Jeffrey (ed.) (2008). My Mistress's Sparrow Is Dead. New York: HarperCollins

Hemingway, Ernest (1953). The Old Man and the Sea. New York: Charles Scribner's Sons.

Hemingway, Ernest (1994). The Old Man and the Sea (tr. to Hebrew by Abraham Yavin). Tel Aviv: Am Oved

Hemingway, Ernest (2005). The Old Man and the Sea (tr. to Hebrew by AlonAltaras). Tel Aviv: Penn.

Hoffman, Eva (1989). Lost in Translation. A Life in a New Language. Harmondsworth: Penguin.

Hutchins, Pat (1986[1968]). Rosie's Walk. New York: Aladdin.

Hutchins, Pat (2006). Rosie's Walk (tr. to Hebrew by Edna Kremer). Tel Aviv: Hakibbutz Hameuchad.

Lispector, Clarice (1998[1960]). Laços de Família. Rio de Janeiro: Rocco.

Lispector, Clarice (1999). Family Ties (tr. to Hebrew by Miriam Tivon). Tel Aviv: Hakibbutz Hameuchad.

McCourt, Frank (1997[1996]). Angela's Ashes. New York: Touchstone.

Naylor, Phyllis Raynolds (1991). Shiloh. New York: McMillan.

Naylor, Phyllis Raynolds (2003). Shiloh (tr. to Hebrew by Amnon Katz). Tel Aviv: Yediot Aharonot.

Naylor, Phyllis Raynolds (2006). Shiloh Season (tr. to Hebrew by Uri Perminger \& Sharon Perminger). Tel Aviv: Yediot Aharonot.

Ondaatje, Michael (1993[1992]). The English Patient. London: Picador.

Pirsig, Robert M. (1974). Zen and the Art of Motorcycle Maintenance. New York: Bantam.

Pynchon, Thomas (1973) Gravity's Rainbow. London: Picador.

Robbe-Grillet, Alain (1957). La Jalousie. Paris: Minuit.

Tammuz, Binyamin (1978). The King Sleeps Four Times a Day. Tel Aviv: Am Oved.

Yizhar, Smilansky (1976). Adventure in a Lake. Tel Aviv: Hakibbutz Hameuchad. 


\section{Secondary Texts}

Bell, Anthea (2006). "Translator's Notebook: Delicate Matters". Gillian Lathey (ed.). The Translation of Children's Literature: A Reader. Clevedon/Buffalo/Toronto: Multilngual Matters, 232-240.

Benveniste, Emile (1966). Problèmes de linguistique générale, 1. Paris: Gallimard.

Coetzee, J.M. (1981). “Time, Tense and Aspect in Kafka's “The Burrow”. MLN 96 (3), 556-579.

Comrie, Bernard (1976). Aspect. Cambridge: Cambridge University Press.

Comrie, Bernard (1985). Tense. Cambridge: Cambridge University Press.

Fleischman, Suzanne (1990). Tense and Narrativity. From Medieval Performance to Modern Fiction. Austin: University of Texas Press and Routledge: London.

Fludernik, Monika (1996). Towards a 'Natural' Narratology. London/New York: Routledge.

Fludernik, Monika (2003). "Chronology, Time, Tense and Experientiality in Narrative”. Language and Literature 12(2), 117-134.

Goldfajn, Tal (1998). Word order and Time in Biblical Hebrew Narrative. Oxford: Oxford University Press.

Hopper, Paul J. (1979). "Aspect and Foregrounding in Discourse". Talmy Givón (ed.) Syntax and Semantics 12. Discourse and Syntax. New York: Academic Press.

Jakobson, Roman (1987). "On Linguistic Aspects of Translation", in Language in Literature. Cambridge, Massachusetts/London: The Belknap Press of Harvard University Press.

Kamp, H. and Rohrer, C. (1983). "Tense in Texts", in R. Bauerle, U. Egli, C. Schwarze, and A. von Stechow, eds., Meaning, Use and Interpretation of Language. Berlin: Walter de Gruyter.

Katz, Amnon (2003). "Translationese Present Tense". Letter published in the Haaretz newspaper (19.11.2003).

Lathey, Gillian (2006). "Time, Narrative Intimacy and the Child: Implications of Tense Switching in the Translation of Picture Books into English". Gillian Lathey (ed.). The Translation of Children's Literature: A Reader. Clevedon/Buffalo/Toronto: Multilngual Matters, 134141 .

Mani, Inderjeet, Pustejovsky, James and Gaizauskas, Rob (eds.) (2005). The Language of Time: A Reader. Oxford/New York: Oxford University Press.

Margolin, Uri (1999). "Of What Is Past, Is Passing, or to Come: Temporality, Aspectuality, Modality, and the Nature of Literary Narrative". David Herman (ed.) Narratologies: New Perspectives on Narrative Analysis. Columbus: Ohio State University Press.

Meschonnic, Henri (1999). Poétique du traduire. Lagrasse: Éditions Verdier.

Padan, Yehiam (2003). "Shiloh". Book review published in the Haaretz newspaper (15.10.2003).

Padan Yehiam (2007). "To Respect the Author of the Book. In the Present". On line at: www.keterbooks.co.i1/p-21_a-39.

Sartre, Jean-Paul (1947). Situations, I. Paris: Gallimard.

Schiffrin, Deborah (1981). "Tense Variation in Narrative". Language 57 (1), 45-62.

Smith, C. S. (1991). The parameter of Aspect. Dordrecht: Kluwer. (2003). Modes of Discourse. Cambridge: Cambridge University Press.

Vaerenbergh, Van Leona (ed.) (2002/1). Linguistics and Translation Studies. Translation Studies and Linguistics. Linguistica Antverpiensia, New Series.

Stinespring, William F. (1970). "The Participle of the Immediate Future and Other Matters Pertaining to Correct Translation of the Old Testament". Harry Thomas Frank and William L. Reed (eds.). Translating and Understanding the Old Testament. New York/Nashville: Abingdon, 64-70.

Wilt, Timothy (ed.) (2003). Bible Translation: Frames of Reference. Manchester: St. Jerome.

${ }^{1}$ Review by B. Brooklyn on the translation of B. Mozetic's Passion (Jacket magazine 33 - July 2007, available at: http://jacketmagazine.com/33/brooklyn-passion.shtml).

${ }^{2}$ We say that a language has tense if it has a set of systematically contrasting verb inflections where the primary semantic function of the terms is to relate the time of the situation to the time of the utterance. Tense thus involves the grammaticalisation of time relations. Aspectual meaning involves not the temporal location of the situation, but rather its temporal flow or segmentation. The progressive, for instance, implies that it is conceived of as taking place, thus as having a more or less dynamic character, rather than being wholly static. 
${ }^{3}$ Few languages have a perfective/imperfective contrast for present time. The present tense in most languages is either imperfective or aspectually neutral.

${ }^{4} \mathrm{~A}$ list of the best-known present tense texts in English would be very extensive, especially since in the last decades the number of present tense texts has risen enormously. Already in many of Dickens's novels there are extended passages with the historical present. Pirsig's Zen and the Art of Motorcycle Maintenance (1974), many of Beckett's works, Coetzee's Waiting for the Barbarians (1980), Ondaatje's The English Patient (1992), McCourt's Angela's Ashes (1996) and Pynchon's Gravity's Rainbow (1973) are only a few well-known English examples.

${ }^{5}$ It is interesting to note that Babar was published in two different English translations, American and British, almost at the same time. Whereas the British version of 1934 chose to change the present tense for the past tense, the American translation of 1933 retained the present tense of the original. See Lathey (2006).

${ }^{6}$ As for another common argument invoked against the use of the historical/narrative present tense in translation - namely, that these present tense uses are not found in Hebrew source texts; i.e. that this present-tense function is not part of the literary conventions of Hebrew, let alone of children's literature in Hebrew - without searching too much, I can cite at least four children's books from four well-known Hebrew writers where one finds extensive use of the historical or narrative present tense: Y. Demiel's The Shabat's Dress of Little Hannale (1990), S. Yzhar's Adventure in a Lake (1976), B. Tammuz's The King Sleeps Four Times a Day (1978) and D. Carmi's A Journey on a Scooter (2003).

${ }^{7}$ The verb form 'beinoni' is a hybrid form: it serves the functions of both a participle - in the periphrastic past tense construction just mentioned as well as in a variety of small clause constructions - and as a main verb encoding present tense (the tense discussed in section 2). The gerundive beinoni ('the kids sat quietly inside the room chewing gums') and the beinoni small clause complement ('I saw Joel running down the street') have no intrinsic tense specification as opposed to the deictic beinoni present tense. For a detailed discussion of the structure of $\mathrm{MH}$ beinoni, see Shlonsky (1997).

8 Further research may clarify whether these different strategies constitute in fact distinct (historical) trends in the translation of aspect into Modern Hebrew.

${ }^{9}$ In fact I would argue, contrary to Stinespring, that the participle is not translated as having a future indication precisely because the prevalent linguistic view has always been that the participle does not have any time specification. So if it is atemporal it cannot have a future reference.

${ }^{10}$ It indicates that bounded events followed each other continuously in the past of either some explicit speech time or a context-specified time (Goldfajn 1998). 